\title{
Potensi Tumbuhan Tembelekan (Lantana camara Linn) Sebagai Sumber Bahan Farmasi Potensial
}

\author{
Laode Rijai \\ Laboratorium Penelitian dan Pengembangan Kefarmasian FARMAKA TROPIS \\ Fakultas Farmasi Universitas Mulawarman
}

\begin{abstract}
ABSTRAK
Tumbuhan Tembelekan dianggap masyarakat sebagai pengganggu atau gulma karena pertumbuhannya yang dahsyat merambat ke segala arah sehingga mengganggu pada kegiatan pembukaan lahan. Manfaat tradisional daun tumbuhan ini dikenal oleh berbagai suku di Indonesia, tetapi hanya sebagai obat luka yang tidak menarik karena obat luka tergolong obat murah di pasaran. Potensi botani yang tampak terhadap tumbuhan Tembelekan adalah pertumbuhannya yang dahsyat sehingga jika memiliki manfaat ekonomi menjadi sangat potensial ditinjau dari penyediaan bahan baku. Beberapa penelitian ilmiah telah dilakukan terhadap daun dan bunga Tembelekan dan terbuktidaunnya sangat potensial sebagai obat luka yang melebihi obat luka bioplacenton dan bunganya bersifat antioksidan yang sangat kuat.Kandungan metabolit sekunder daun dan bunganya juga sangat bervariasi sehingga masih memungkinkan potensi-potensi lainya dalam bidang farmasi.
\end{abstract}

Kata Kunci: Tembelekan (Lantana camara L), sumber bahan farmasi potensial

\section{PENDAHULUAN}

Potensi farmasi suatu bahan yaitu potensi yang terkait dengan kegunaan sebagai obat, makanan, dan kosmetik yang sehat dan menyehatkan. Bahan yang berguna atau berpotensi dalam bidang farmasi tersebut dapat bersumber dari bahan alami dan sintetik (buatan). Bahan alami yang sangat dominan sebagai sumber bahan farmasi adalah tumbuhan, dankhusus untuk obat dan kosmetik juga dapat bersumber dari sintetik. Sejarah membuktikan bahwa perkembangan kedokteran dan farmasi berawal dari kemampuan manusia meracik obat dari bahan alami tersebut. Kemajuan ilmu pengetahuan dan teknologi akhirnya manusia dapat mensintetik bahan farmasi terutama obat sehingga penggunaan bahan alami menjadi ditinggalkan. Kesangsian kebenaran khasiat bahan alami sebagai bahan obat merupakan penyebab utama berkembangnya obat sintetik dan akhirnya obat-obat bahan alami menjadi dianggap tidak rasional. Khasiat bahan alami sebagai obat bukan tidak rasional melainkan kemampuan manusia sangat terbatas untuk menjelaskannya secara rasional. Fakta klinik berbagai khasiat bahan alami semakin berkembang juga dan akhirnya sejak tahun 1990-an hingga sekarang ada kecenderungan kembali kepada bahan alami untuk pengobatan. Seiring dengan peristiwa tersebut perkembangan ilmu pengetahuan dan teknologi pengkajian bahan alami untuk menjadi obat rasional juga meningkat dan akhirnya hingga saat ini obat-obat dari bahan alami tampaknya akan kembali digunakan manusia dengan kebenaran ilmiah yang lebih memadai dari sebelumnya.

Sehubungan dengan itu, kegiatan pencarian sumber-sumber bahan alami untuk kebutuhan obat dan kosmetik saat ini semakin meningkat termasuk tingkat keilmiaan pencarian karena ilmu dan teknologi telah tersedia. Sumber-sumber bahan yang sangat potensial sebagai sumber bahan farmasi adalah tumbuhan karena memiliki keragaman metabolit sekunder yang tinggi, kemudahan 
budidaya, dan khusus Indonesia memiliki keragaman spesies tumbuhan yang melimpah. Pencarian sumber bahan farmasi lebih diprioritaskan pada tumbuhan yang tidak termanfaatkan selama ini, namun tumbuhan tersebut harus mudah dibudidayakan. Tembelekan (L. camara, L.) seperti terlihat pada Gambar 1, merupakan tumbuhan liar yang selama ini dianggap sebagai gulma oleh masyarakat karena pertumbuhannya sangat dahsyat yang merambat keberbagai arah sehingga mengganggu tanaman komoditi petani. Pertumbuhan Tembelekan yang dahsyat sebenarnya merupakan potensi yang luar biasa jika dapat diungkap secara ilmiah kegunaannya. Pertumbuhan dahsyat akan menghasilkan jumlah populasi yang banyak dalam waktu singkat sehingga sangat baik ditinjau dari segi ketersediaan bahan baku. Manfaat tradisional daun tumbuhan Tembelekan sebagai obat luka sangat manjur, namun dari segi ekonomi potensi obat luka sangat rendah sehingga tidak menarik pada berbagai peneliti dan produsen. Potensi suatu tumbuhan pada bidang farmasi umumnya tidak bersifat
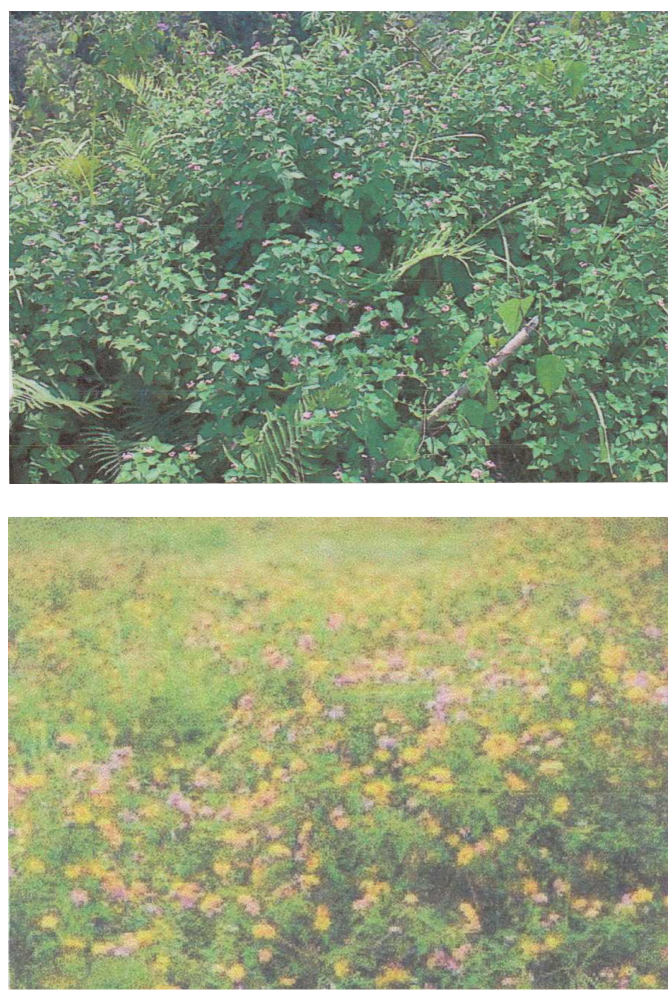

Gambar 1. Tumbuhan Tembelekan (L. camara) tunggal sehingga diperlukan usaha-usaha untuk memperluas informasi tentang manfaatnya melalui suatu kegiatan penelitian ilmiah. Eksplorasi manfaat suatu tumbuhan dapat dilakukan pada skala simplisia, esktrak, hingga molekul kandungannya. Eksploitasi tumbuhan atau hutan yang dilakukan oleh masyarakat Indonesia selama ini telah menyebabkan banyaknya spesies yang punah bahkan di antaranya belum dikenal secara ilmiah. Keadaan ini merupakan bencana sehingga diperlukan usaha dalam bentuk lain untuk melindungi berbagai spesies ciptaan Tuhan tersebut. Penelitian yang mengarah pada pemanfaatan kefarmasian bukanlah kegiatan yang aman bagi spesies sehingga dimulai dari spesies yang mudah untuk dibudidayakan. Tumbuhan Tembelekan adalah salah satu spesies potensial ditinjau dari segi budidaya sehingga akan terus dilakukan penelitian secara mendalam tentang potensi farmasi yang dimilikinya yang pada akhirnya tumbuhan tersebut nantinya menjadi suatu komoditi yang bernilai ekonomi.
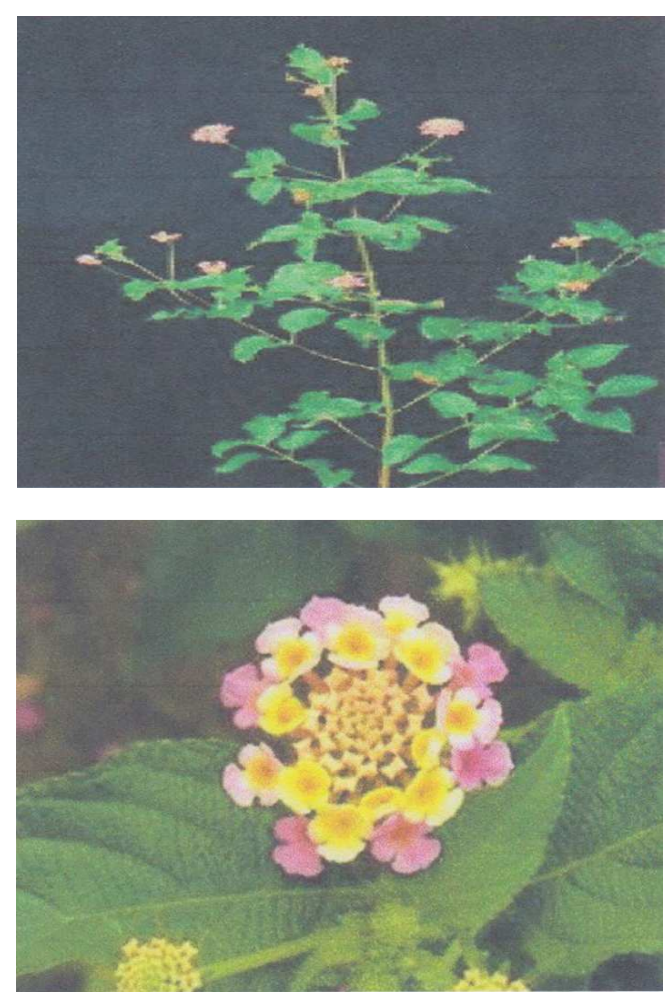


\section{METODE PENELITIAN}

Penelitian penelusuran potensi berbagai tumbuhan dilakukan secara terus menerus oleh Laboratorium Penelitian dan Pengembangan Kefarmasian FARMAKA TROPIS dengan sasaran menemukan suatu tumbuhan yang dapat segera termanfaatkan sebagai bahan farmasi.Artikel ilmiah ini melaporkan beberapa hasil penelitian tersebut yang telah dilaksanakan yaitu potensi tumbuhan Tembelekan sebagai sumber bahanantioksidan tembelekan, kemampuan sebagai obat luka, dan golongan metabolit sekundernya.

\section{A. Penyiapan Bahan Tumbuhan}

Daun dan bunga tumbuhan Tembelekan diambil di Samarinda di Kebun Raya Universitas Mulawarman. Daun dan bunga tumbuhan tersebut dikeringkan dengan sinar matahari untuk keperluan ekstraksi. Daun dan bunga yang telah dinyatakan kering selanjutnya diblender untuk mendapatkan serbuk kering yang siap untuk diekstraksi.

\section{B. Ekstraksi dan Fraksinasi}

Serbuk kering daun dan bunga tumbuhan tembelekan masing-masing diekstraksi dengan pelarut etanol dengan metode maserasi dingin. Bobot serbuk kering daun yang digunakan $500 \mathrm{~g}$ dilakukan ekstraksi dengan pelarut etanol $70 \%$ yang berlangsung selama 13 hari termasuk kegiatan penguapan pelarut dengan rotavapor dan juga penguapan pada udara terbuka untuk meminimalisasi pelarut etanol dalam ekstrak. Hasil penguapan pelarut tersebut ditemukan ekstrak pekat etanol daun Tembelekan $84,8 \mathrm{~g}$ yang berarti rendemen ekstraknya $16,96 \%$. Ekstrak yang diperoleh tersebut siap untuk diuji. Selanjutnya, serbuk kering bunga tembelekan adalah 134,8 g yang dimaserasi dengan etanol $70 \%$ selama 8 hari. Ekstrak bunga tembelekan yang diperoleh berjumlah 28,6 g yang berarti rendemen ekstraknya adalah 21,21 $\%$. Ekstrak-ekstrak tersebut telah siap untuk perlakuan selanjutnya.

\section{Pengujian Potensi Obat Luka Ekstrak Daun}

Uji potensi sebagai obat luka dilakukan secara in vivo menggunakan hewan uji tikus putih. Prinsip pengujian pengamatan terhadap kesembuhan luka berdasarkan waktu. Uji potensi sebagai luka hanya dilakukan terhadap daun sesuai dengan potensi tradisionalnya.

\section{a. Penetapan Konsentrasi Ekstrak untuk Pengujian}

Prinsip penentuan seri konsentrasi uji dilakukan secara acak yaitu dengan mencobakan konsentrasi yang dipilih secara acak tersebut. Konsentrasi yang ditetapkan adalah konsentrasi yang memberikan efek dibandngkan dan kelompok kontrol. Konsentrasi ekstrak yang ditetapkan yaitu $5 \%$; 17\%; dan 30 $\%$. Pada seri konsentrasi tersebut menunjukkan adanya efek ekstrak sebagai obat luka.

\section{b. Penyiapan Hewan Uji}

Hewan uji yang digunakan tikus putih dikelompokan dalam 4 kelompok dan setiap kelompok terdiri dari 3 ekor sehingga jumlah hewan uji yang diperlukan adalah 12 ekor. Kelompok hewan uji terdiri dari kelompok kontrol (tanpa perlakuan), kelompok eksperimen atau perlakuan yaitu perlakuan berdasarkan konsetrasi uji yang digunakan. Setiap ekor hewan uji yang masuk kategori kelompok tersebut di lukai hingga ukuran mencapai luas $4 \mathrm{~m}^{2}$.

\section{c. Pengujian Potensi Obat Luka}

Pengujian dilaksanakan secara bertahap atau dalam waktu yang tidak bersamaan antara kelompok satu dan lainnya untuk 
menghindari tingkat kerumitan pengujian. Kelompok kontrol atau kelompok yang tidak diberikan ekstrak, penyembuhan terjadi secara alami, sedangkan kelompok eksperimen diberikan ekstrak sesuai dengan konsentrasi uji yang telah ditetapkan. Indikator penyembuhan adalah penutupan luka yang sempurna pada selang waktu tertentu sehingga data dalam satuan waktu yaitu hari.

\section{Pengujian Antioksidan Ekstrak Bunga}

Antioksidan adalah sifat kimia suatu molekul yang dapat dimanfaatkan dalam bidang farmasi. Antioksidan bahan alami pada umumnya bersifat positif terhadap kesehatan yaitu khas untuk meredam radikal bebas yang berbahaya. Uji antioksidan tumbuhan Tembelekan dilakukan terhadap bunga. Uji antioksidan dilakukan terhadap senyawa radikal bebas DPPH yaitu suatu senyawa radikal sintetik yang cukup stabil. Ekstrak yang diuji pada pengujian antioksidan adalah ekstrak pekat etanol, fraksi $n$-heksana, fraksi etilasetat, dan fraksi $n$-butanol. Seluruh fraksi tersebut diperoleh dari fraksi pekat etanol melalui fraksinasi dengan teknik cair-cair yang dilaksanakan secara gradien.

\section{a. Penyiapan Larutan Senyawa Radikal DPPH}

Larutan DPPH dibuat pada konsetrasi 40 ppm dalam pelarut metanol Pa. Larutan DPPH tersebut diusahakan diletakan pada wadah berwarna gelap untuk mencegah sinar UV yang dapat merusak struktur molekul DPPH.

\section{b. Penentuan Konsentrasi Ekstrak Uji}

Prinsip penentuan konsentrasi uji antioksidan adalah nilai absorbansi membentuk garis linier terhadap penurunan absorbansi DPPH setelah penambahan ekstrak. Hal ini sesuai dengan tujuan pengujian yaitu menetapkan tingkat kekuatan aktvitas antioksidan dengan satuan Inhibitor Concentration (IC50). Hasil penentuan konsentrasi uji untuk pengujian antioksidan ditunjukkan pada Tabel 1.

\section{c. Pengujian Antioksidan}

Pengujian antioksidan dilakukan dengan cara penambahan $2 \mathrm{~mL}$ larutan DPPH ke dalam larutan ekstrak pada setiap seri konsentrasi uji dan dibiarkan selama 3045 menit dengan harapan terjadi reaksi kimia antara metabolit sekunder ekstrak dengan DPPH. Campuran larutan tersebut dikocok dalam tabung reaksi lalu dipindahkan ke dalam Cuvet Spektrometer UV-VIS untuk diukur nilai absorbansinya. Sebelum perlakuan ekstraksi terhadap larutan DPPH terlebih dahulu dilakukan pengukuran absobansi larutan DPPH pada panjang gelombang maksimum yang dicapai yaitu sekitar 510-516 nm. Pengujian dilakukan tiga kali hingga 5 kali untuk menghindari kesalahan setiap seri konsentrasi.

Tabel 1. Konsentrasi uji antioksidan ekstrak bunga tumbuhan Tembelekan (L. camara)

\begin{tabular}{clcccc}
\hline & & \multicolumn{4}{c}{ Konsentrasi Uji dalam ppm } \\
\cline { 3 - 6 } No. & \multicolumn{1}{c}{ Ekstrak } & I & II & III & IV \\
\hline 1. & Ekstrak pekat etanol & 20 & 40 & 80 & 160 \\
2. & Ekstrak fraksi $n$-heksana & 40 & 60 & 80 & 100 \\
3. & Ekstrak fraksi etilasetat & 5 & 25 & 45 & 65 \\
4. & Ekstrak fraksi $n$-butanol & 5 & 25 & 45 & 65 \\
\hline
\end{tabular}




\section{E. Pengujian Metabolit Sekunder}

Uji metabolit sekunder daun tumbuhan Tembelekan dilakukan terhadap senyawa tunggal hasil isolasi dari fraksi $n$-heksana dan etilasetat, sedangkan uji metabolit sekunder terhadap bunga dilakukan dalam bentuk skrining ekstrak pekat etanol.

\section{a. Isolasi Metabolit Sekunder}

Teknik isolasi yang digunakan adalah Kromatografi Kolom (KK) menggunakan silika gel $254 \mathrm{~nm}$ dan ukuran kolom 100 $\mathrm{mL}$. Senyawa yang diperoleh berdasarkan penampakan spot hasil Kromatografi Lapis Tipis (KLT) dengan berbagai nilai Rf yang ditemukan. Setiap spot pada plat KLTdengan nilaiRf tertentu merupakan senyawa tunggal atau beberapa senyawa dan terhadap setiap spot tersebut dilakukan identifikasi golongan metabolit sekunder menggunakan pereaksi khas.

\section{1). Isolasi Metabolit Sekunder Fraksi n-Heksana}

Eluen yang digunakan untuk pemisahan metabolit sekunder fraksi $n$-heksana adalah Kloroform-Metanol dengan perbandingan $4 \quad$ :1 yang merupakan perbandingan terbaik dari hasil pencarian eluen. Jumlah spot senyawa yang berhasil dipisahkan dengan eluen tersebut adalah 9 spot yang menggambarkan bahwa minimal terdapat 9 senyawa dengan nilai Rf yang berbeda secara signifikan.

\section{2). Isolasi Metabolit Sekunder Fraksi Etilasetat}

Eluen yang digunakan untuk pemisahan metabolit sekunder fraksi etilasetat adalah Kloroform-Metanol dengan perbandingan 6:1 yang terbaik dari hasil pencarian eluen. Jumlah spot senyawa yang berhasil dipisahkan dengan eluen tersebut adalah 7 spot yang menggambarkan bahwa minimal terdapat 7 senyawa dengan nilai Rf yang berbeda secara signifikan.

\section{3). Uji Golongan Metabolit Sekunder Daun Tembelekan.}

Sampel daun yang dilakukan uji golongan metabolit sekunder adalah ekstrak fraksi etilasetat dan $n$-heksana yang diarahkan pada spot hasil isolasi dengan teknik KK. Tujuannya adalah untuk mengetahui lebih spesifik terhadap senyawa tertentu. Golongan metabolit sekunder yang diuji terhadap spot senyawa yang diperoleh adalah steroid, alkaloid, dan flavanoid karena ketiga golongan tersebut merupakan senyawa polaritas rendah yang dapat terekstraksi dengan pelarut etilasetat maupun $n$ heksana. Pengujian menggunakan pereaksi khas terhadap golongan metabolit sekunder tersebut. Teknik pengujian dilakukan dengan penyemprotan setiap spot dengan larutan pereaksi dan jugadengan pengujian pada larutan ekstrak masing-masing fraksi.

\section{4). Uji Metabolit Sekunder Bunga Tumbuhan Tembelakan}

Ekstrak yang dilakukan pengujian metabolit sekunder adalah ekatrak pekat etanol, ekstrak fraksi $n$-butanol, ekstrak fraksi etilasetat, dan ekstrak fraksi $n$ heksana. Golongan metabolit sekunder yang diuji adalah alkaloid, flavanoid, triterpen, tanin, antoisianin, saponin khusus terhadap ekstrak pekat etanol, etilasetat, dan n-butanol, serta steroid. Teknik pengujian adalah perlakuan pereaksi khas terhadap semua metabolit sekunder yang diidentifikasi dengan menggunakan wadah plat tetes. Hasil reaksi yang menunjukkan adanya 
golongan metabolit sekunder diberikan kode positif, dan jika dominan positif 2 dan jika sangat dominan positif 3 .

\section{HASIL DAN PEMBAHASAN}

Potensi kefarmasian tumbuhan Tembelekan yang dilaporkan (a) potensi sebagai obat luka yang merupakan kegunaan tradisional daun tumbuhan tersebut selama ini (b) antioksidan bunga karena bunga tumbuhan Tembelekan berwarna warni yang menggambarkan flavanoid yang pada umumnya memiliki aktivitas antioksidan yang cukup baik (c) golongan metabolit sekunder senyawa yang diisolasi dari fraksi $n$-heksana dan etilasetat daun tumbuhan tembelekan serta (d) golongan metabolit sekunder bunga.

\section{A. Potensi Daun Tembelakan ( $L$. camara) Sebagai Obat Luka}

Potensi ekstrak pekat etanol daun tembelakan sebagai obat luka dilakukan dengan uji in vivo terhadap hewan uji tikus putih. Penentuan potensi ekstrak dibandingkan dengan kontrol normal atau penyembuhan luka tanpa pemberian ekstrak yang dianggap sebagai obat. Selain itu juga dilakukan uji potensi membandingkannya dengan obat luka yang telah ada yaitu bioplacenton. Hasil pengujian ditunjukkan pada Tabel 2.

Hasil pengujian tersebut menunjukkan bahwa ekstrak pekat etanol daun tembelekan sangat potensial sebagai obat luka karena melampaui potensi obat bioplacenton, terlebih jika dibandingkan dengan penyembuhan normal di atas 50\% lebih baik jika menggunakan daun tembelakan. Bukti ilmiah ini mendukung bukti klinik secara tradisional yang selama ini dilakukan oleh masyarakat. Aspek yang dapat ditindak lanjuti adalah pencarian senyawa yang yang diduga samgat berpotensi atau membuat dalam bentuk sediaan untuk selanjutnya dilakukan uji stabilitas aktivitas sebagai obat luka.

Tabel 2. Potensi ekstrak pekat etanol daun tembelekan (L. camara) sebagai obat luka dengan menggunakan hewan uji tikus putih

\begin{tabular}{clc}
\hline No. & Konsetrasi Uji Ekstrak dan Pembanding & Lama Penyembuhan Luka (hari) \\
\hline 1. & Konsentrasi uji 5\% & 3,6 \\
2. & Konsentrasi uji 17,5\% & 3,5 \\
3. & Konsentrasi uji 30\% & 3 \\
4. & Bioplacenton (pembanding obat) & 4 \\
5. & Aquadest (pembanding normal) & 6,5 \\
\hline
\end{tabular}

Sumber: Esa (2011)

\section{B. Potensi Bunga Tembelekan ( $L$. camara) Sebagai Antioksidan}

Potensi antioksidan bunga tumbuhan tembelekan yang dilaporkan adalah ekstrak pekat etanol, fraksi $n$-heksana, fraksi etilasetat, dan fraksi $n$-butanol. Bunga tumbuhan tembelekan yang berwarna-warni merupakan alasan utama pengujian potensi antioksidan. Hasil pengujian antioksidan tersebut ditunjukkan pada Tabel 3.
Tabel 3. Potensi antioksidan ekstrak bunga tumbuhan tembelekan (L. camara) terhadap senyawa radikal bebas DPPH

\begin{tabular}{clc}
\hline No. & \multicolumn{1}{c}{ Ekstrak } & $\begin{array}{c}\text { Nilai } \mathrm{IC}_{50} \\
(\mathrm{ppm})\end{array}$ \\
\hline 1. & Ektrak pekat etanol & 65,94 \\
2. & Ekstrak fraksi $n$-heksana & 53,66 \\
3. & Ekstrak fraksi etilasetat & 63,58 \\
4. & Ekstrak fraksi $n$-butanol & 27,53 \\
\hline
\end{tabular}

Sumber: Amarullah (2011) 
Seluruh ekstrak bunga daun tembelekan memiliki aktivitas antioksidan yang sangat baik yaitu kurang dari 200 ppm, yang mana seluruh bahan yang memiliki aktivitas antioksidan $<200$ ppm termasuk kategori antioksidan yang dapat dimanfaatkan dalam bidang kesehatan atau sebagai bahan farmasi (Rapael, 1991). Perlakuan bunga sebagai sampel adalah bunga yang telah dikeringkan pada oven sehingga jika terdapat senyawa yang tidak tahan panas akan rusak pada saat pemanasan $40{ }^{\circ} \mathrm{C}$. Karena itu aktivitas antioksidan yang ditunjukkan dapat berasal dari senyawa yang stabil dengan pemanasan.

\section{Kandungan Metabolit Sekunder Tembelekan (L. camara)}

Ekstrak yang diidentifikasi kandungan metabolit sekundernya adalah ekstrak fraksi etilasetat dan ekstrak fraksi $n$ heksana daun, sedangkan untuk bunga dilakukan terhadap seluruh ekstrak yang diperoleh yaitu ekstrak pekat etanol, ekstrak fraksi $n$-butanol, ekstrak fraksi etilasetat, dan ekstrak fraksi $n$-heksana.

\section{a. Profil Metabolit Sekunder Daun Tembelekan}

Ekstrak yang dilakukan identifikasi golongan metabolit sekunder daun tembelekan adalah terhadap senyawa hasil pemisahan dengan teknik KK dari fraksi etilasetat dan $n$-heksana. Hasil identifikasi metabolit sekunder daun tembelekan ditunjukan pada Tabel 4.

Kegunaan data tersebut adalah tindak lanjut pemisahan untuk mendapatkan senyawa tersebut dengan teknik sederhana yaitu penggunaan Kromatografi Kolom. Jumlah senyawa tersebut belum maksimal karena masih terdapat spot yang tumpang tindih sedangkan jumlah yang ditampilkan telah memiliki bentuk yang murni dan nilai $\mathrm{Rf}$ yang berbeda secara signifikan antara spot satu dan lainnya. Kebenaran pemisahan juga diindikasikan dengan golongan metabolit sekunder yang ditemukan yaitu flavanoid, alkaloid, dan steroid yang kesemuanya adalah dapat terekstraksi pada pelarut n-heksana dan etilasetat dengan tingkat polaritas yang berbeda.

Tabel 4. Profil golongan metabolit sekunder daun tembelakan (L. camara) suatu profil senyawa dari fraksi etilasetat dan n-heksana hasil isolasi dengan teknik KK

\begin{tabular}{|c|l|c|l|}
\hline No & \multicolumn{1}{|c|}{ Ekstrak Fraksi } & Jumlah Senyawa & \multicolumn{1}{|c|}{ Profil Golongan Senyawa } \\
\hline 1 & Ekstrak fraksi n-heksana & 9 & Steroid dan flavanoid \\
\hline 2 & Ekstrak fraksi etilasetat & 7 & Steroid dan flavanoid \\
\hline
\end{tabular}

Sumber: Ajeng dan Utami (2013)

\section{b. Profil Metabolit Sekunder Bunga Tumbuhan Tembelekan (L. camara)}

Ektrak bunga tembelekan yang dilaporkan kandungan metabolit sekundernya adalah ekstrak pekat etanol, ekstrak fraksi $n$-butanol, ekstrak fraksi etilasetat, dan ekstrak fraksi n-heksana. Hasil identifikasi metabolit sekunder terhadap seluruh ekstrak tersebut ditunjukkan pada Tabel 5.
Bunga tumbuhan Tembelekan tidak mengandung antosianin yang sebelumnya diduga karena warna-warni bunga pada umumnya keunguan, akan tetapi kandungan flavanoidnya sangat dominan pada ekstrak pekat dan fraksi etilasetat. Seluruh metabolit sekunder tersebut diduga sangat stabil dengan panas karena pengeringan dilakukan dengan teknik pemanasan oven pada temperatur $40-60$ ${ }^{\circ} \mathrm{C}$. 
Tabel 1.5. Golongan metabolit sekunder bunga Tembelekan (L. camara)

\begin{tabular}{|c|l|l|c|}
\hline No & Ekstrak Bunga Tembelekan & Golongan Metabolit Sekunder & Kuantitas \\
\hline \multirow{2}{*}{1} & \multirow{2}{*}{ Ekstrak pekat etanol } & Alkaloid & ++ \\
\cline { 3 - 4 } & & Flavanoid & +++ \\
\cline { 3 - 4 } & & Tanin & +++ \\
\cline { 3 - 4 } & & steroid & ++ \\
\hline 2 & Ekstrak fraksi $n$-butanol & Tanin & ++ \\
\hline 3 & Ekstrak fraksi etilasetat & Flavanoid & +++ \\
\cline { 3 - 4 } & & Steroid & ++ \\
\hline 4 & Ekstrak fraksi $n$-heksana & Alkalod & ++ \\
\cline { 3 - 4 } & & Steroid & ++ \\
\hline
\end{tabular}

Sumber: Amrullah (2013)

Berdasarkan hasil-hasil penelitian tersebut maka tumbuhan tembelekan memiliki potensi kefarmasian yang cukup baik yaitu sebagai antioksidan untuk bunganya dan obat luka untuk daunya. Potensi-potensi tersebut secara ilmiah dapat dikembangkan yaitu melalui penelitian akitvitas lainnya seperti sitotoksik untuk daunnya, antibakteri secara khsusus, serta bebagai potensi lainnya. Tumbuhan Tembelekan dengan pertumbuhannya yang dahsyat dalam waktu yang singkat merupakan potensi yang luar biasa sehingga predikatnya sebagai gulma akan segera ditiadakan.

\section{KESIMPULAN}

Tumbuhan Tembelekan (L. camara) sangat berpotensi sebagai sumber bahan farmasi yaitu sebagai sumber bahan antioksidan dan sebagai bahan obat luka. Secara rinci potensi tembelekan adalah:

1. Potensi daun tembelekan (L. camara) sebagai obat luka melampaui potensi obat Bioplacenton dengan indikator lebih cepat meneyembuhkan.

2. Daun tumbuhan Tembelekan ( $L$. camara) sangat berpotensi sebagai sumber antioksidan yaitu ekstrak pekat etanol, ekstrak fraksi $n$ butanol, ekstrak fraksi etilasetat, dan ekstrak fraksi $n$-heksana semuanya memiliki potensi antioksidan yang sangat baik yaitu memiliki nilai IC50 kurang dari 100 ppm
3. Kandungan metabolit sekundernya sangat beragam sehingga masih memungkinkan memiliki potensi kefarmasian lainnya.

\section{REKOMENDASI}

Rekomendasi penting untuk tumbuhan Tembelekan adalah penelitian kefarmasian yang lebih komplek untuk menemukan potensi yang paling prospektif sehingga anggapan masyarakat terhadap tembelekan sebagau gulma dapat segera dihilangkan. Laporan ilmiah ini cukup untuk melakukan penelitian lebih lanjut terhadap tumbuhan tembelekan.

\section{UCAPAN TERIMAKASIH}

Terimakasih kepada Kepala dan seluruh petugas Laboratorium Penelitian dan Pengembangan Kefarmasian FARMAKA TROPIS Fakultas Farmasi Universitas Mulawarman sebagai tempat kegiatan penelitian kefarmasian terutama pemanfaatan sumberdaya alam.

\section{DAFTAR PUSTAKA}

1. Ajeng, P. A., 2013. Isolasi dan uji aktivitas senyawa metabolit sekunder dari ekstrak fraksi n-Heksana daun tumbuhan Tembelekan (L. camara). Skripsi. Fakultas Farmasi UNMUL. 
2. Amrullah, S., 2012. Identifikasi Metabolit Sekunder dan Antioksidan bunga tumbuhan Tembelekan $L$. camara). Skripsi. Fakultas Farmasi, Universitas Mulawarman. Samarinda.

3. Esa, E. 2011. Uji potensi obat luka ekstrak pekat etanol daun tumbuhan Tembelekan (L. camara) terhadap hewan uji tikus putih. Skripsi. Fakultas Farmasi Universitas Mulawarman. Samarinda.
4. Rapael, 1991. Natural Products: a Laboratory Guide, Second Ed. Academic Press, Inc. London.

5. Utami, T., 2013. Isolasi dan uji aktivitas ekstrak fraksi etilasetat daun tumbuhan Tembelekan (L. camera). Skripsi. Fakultas Farmasi Universitas Mulawarman. Samarinda. 